Uniciencia. Vol. 35(1), e15189. January-June, 2021

URL: https://www.revistas.una.ac.cr/uniciencia

Email: revistauniciencia@una.cr
Doi: https://dx.doi.org/10.15359/ru.35-1.0

E-ISSN: 2215-3470

CC: BY-NC-ND

Editorial section

\title{
Uniciencia journal adopts the continuous publication model
}

\author{
Published: Jan/31/2021
}

In 2018, the journal Uniciencia began an evaluation process on the number of papers received and evaluated, and the evaluation and editorial stages, with a view to assessing its periodicity in the light of current international requirements. Technical and administrative consultations were carried out with different instances such as the Faculty of Exact and Natural Sciences, the Vice-Rectory of Research, the Publications Department of the Universidad Nacional (UNA) in Costa Rica, the journal management consultancy of the UNA and other universities, as well as national and international accrediting agencies (Latindex, Redalyc, Scielo and Scopus Elsevier), among others.

It is with great pleasure and pride that, as a result of this evaluation and the suggestions of the entities involved, on 27 November 2020 the Editorial Committee of the journal Uniciencia unanimously agreed to change the periodicity from biannual to a continuous publication model, starting with the publications of 2022. Thus, during 2021, a transition process will be carried out in which the current periodicity will be maintained.

Adopting this model in a formal way is innovative and is a huge step and challenge for this publication. It is worth noting that the main objective is to manage a journal with greater impact and greater dissemination at national and international level, and whose purpose is to provide the most benefit to our readers, authors and, in general, to our society.

Greetings,

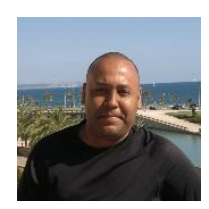

\section{Yuri Morales-López}

Editor in Chief. Uniciencia journal

email: revistauniciencia@una.cr

Universidad Nacional, Costa Rica

www.revistas.una.ac.cr/index.php/uniciencia

Uniciencia is protected by Attribution-NonCommercial-NoDerivs 3.0 Unported 
Uniciencia. Vol. 35(1), e15189. January-June, 2021

URL: https://www.revistas.una.ac.cr/uniciencia

Email: revistauniciencia@una.cr
Doi: https://dx.doi.org/10.15359/ru.35-1.0

E-ISSN: $2215-3470$

CC: BY-NC-ND

Sección editorial

\title{
La revista Uniciencia adopta el modelo de publicación continua
}

\author{
Publicado: Enero/31/2021
}

En 2018, la revista Uniciencia inició un proceso de evaluación sobre la cantidad de trabajos recibidos y evaluados, y las etapas de evaluación y editoriales, en miras de valorar su periodicidad a la luz de las exigencias internacionales actuales. Se realizaron consultas técnicas y administrativas a distintas instancias como la Facultad de Ciencias Exactas y Naturales, la Vicerrectoría de Investigación, el Departamento de Publicaciones de la Universidad Nacional, la asesoría en la gestión de revistas de la UNA y de otras universidades, así como a entes acreditadores nacionales e internacionales (Latindex, Redalyc, Scielo y Scopus Elsevier), entre otros.

Con enorme gusto y orgullo comunico que, como resultado de esta evaluación y las sugerencias de los entes involucrados, el 27 de noviembre de 2020 el Comité Editorial de la revista Uniciencia tomó el acuerdo, de forma unánime, de realizar el cambio de periodicidad de manera semestral hacia el modelo de publicación continua, a partir de las publicaciones de 2022. Así, durante 2021 se realiza un proceso de transición en el que se mantiene la periodicidad actual.

Adoptar este modelo de manera formal es innovador y es un enorme paso y reto para esta publicación. Valga señalar que el objetivo principal es gestionar una revista con mayor impacto y de mayor divulgación a nivel nacional e internacional, y cuyo fin es dar el mayor beneficio a nuestros lectores, autores y, en general, a nuestra sociedad.

Saludos,

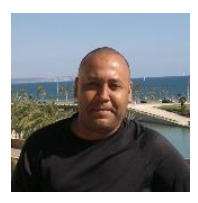

\section{Yuri Morales-López}

Editor in Chief. Uniciencia journal

email: revistauniciencia@una.cr

Universidad Nacional, Costa Rica

www.revistas.una.ac.cr/index.php/uniciencia 